\title{
ISSUES IN INCOME TAX ACCOUNTABILITY: AN ANALYSIS OF THE RENTAL HOUSING SECTOR
}

\author{
ALEX S. MACNEVIN ${ }^{*}$
}

Many of the proponents of improved accountability in taxation support the view that tax changes can be meaningfully classified as either "lax policy" changes or "tax expenditure" changes. While echoing the call for improved accountability, the author questions the validity of maintaining this dichotomy as he undertakes a critical assessment of income tax changes in the rental housing sector between 1972 and 1992. In addition to discussing changes that directly impact the rental housing sector, the author includes measures that target closely related sectors, such as the construction sector. He concludes that the traditional dichotomy is neither feasible nor meaningful and calls for $a$ more integrated framework. Such an integrated approach would ideally ensure that all potential ramifications of tax changes would be taken into account. This would, in turn, lay the groundwork for improved features that would comprise such an integrated framework by reference to analytical welfare economics.
Pour bon nombre d'adeptes d'une meilleure responsabilité fiscale, les changements proposés se classent en deux catégories - ils concernent soit la politique fiscale soit les dépenses fiscales. Tout en reconnaissant la nécessité d'améliorer la situation présente, l'auteur remet en question la validité de cette dichotomie. Son examen critique porte sur les changements survenus dans le secteur des logements locatifs de 1972 à 1992. Dans le cadre de cette discussion, l'auteur s'intéresse également aux mesures qui touchent des secteurs connexes, celui de la construction notamment. Il conclut que la dichotomie traditionnelle n'est ni réalisable ni valable. Il préconise une approche plus intégrée, inspirée d'une économie de bien-être analytique, qui tiendrait compte de toutes les ramifications possibles d'une réforme fiscale.

\section{TABLE OF CONTENTS}

I. INTRODUCTION . . . . . . . . . . . . . . . 667

II. FEDERAL RENTAL HOUSING TAX CHANGES, 1972-1992 . . . . . . . . . . . . . . . . . . . . . 669

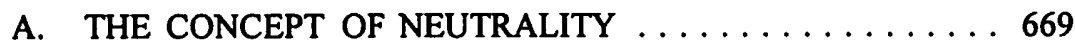

B. RENTAL HOUSING INCOME TAX

CHANGES, $1972-1992 \ldots \ldots \ldots \ldots \ldots \ldots \ldots$

III. IMPLICATIONS FOR ACCOUNTABILITY

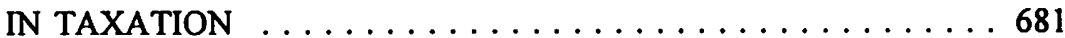

IV. CONCLUDING COMMENTS $\ldots \ldots \ldots \ldots \ldots \ldots \ldots \ldots 63$

\section{INTRODUCTION}

Criticism of current practices relating to tax accountability is fairly common. For example, at a 1990 conference sponsored by the Law Reform Commission of Canada on government accountability, the view was expressed that there were significant deficiencies in the legal accountability framework applying to tax and other financial

Currently an economic consultant in Halifax, Nova Scotia, the author was formerly an economist with both the Economic Council of Canada and the Tax Policy Branch of the federal Department of Finance. 
incentives. ${ }^{1}$ Among the areas identified as deficient are the following: federal/provincial jurisdiction; legislative structure; advance notice and comment procedures; and natural justice and procedural fairness. ${ }^{2}$ Dissatisfaction with other substantive areas of tax accountability has also been expressed by the Office of the Auditor General (OAG). In the view of the OAG, tax incentives and subsidies are not systematically documented, costed or evaluated in a manner that parallels the treatment accorded government direct expenditure programs. ${ }^{3}$

Underlying the position of many proponents of the need for improved accountability in taxation, either explicitly or implicitly, is the view that tax changes can meaningfully be divided into two fairly distinct categories - "tax policy" changes and "tax expenditure" changes. ${ }^{4}$ At face value, measures viewed as being in the "tax policy" category are those that refine the definition of the various tax bases or preserve the integrity of those bases. Changes falling into the "tax expenditure" category, on the other hand, are viewed as those that are intentional deviations from the reference tax bases; in principle, these measures are introduced to achieve explicit social and economic objectives, such as the redistribution of income or to provide incentives for particular industries, regions or groups of taxpayers. The possibility of clearly distinguishing measures that fall into the one category from those that fall into the other would imply that tax expenditure evaluation criteria - namely, assessment of the costeffectiveness with which particular tax expenditures accomplish social and economic objectives in comparison with other potential tax or non-tax instruments - could be implemented that would be distinct from normal tax policy considerations.

In this article, I review income tax changes targeted at the rental housing sector over two decades and assess the usefulness of the distinction between tax policy and tax expenditure changes for purposes of tax accountability. Based on my review of these changes, I conclude that the dichotomous view is not particularly meaningful or useful in the context of tax policy design and evaluation. I suggest that a more integrated approach to tax design and evaluation is warranted, and preferable to one which attempts to apply a narrow doctrinaire tax policy approach to one category of tax changes and another completely different tax expenditure approach to another. While the article is not concerned explicitly with the legal structures and channels of accountability mentioned above, it is unlikely that substantive improvements in that

The proceedings of the conference were published recently in a special edition of this journal (see The Power of the Purse: Financial Incentives as Regulatory Instruments (1993) 31 Alta. L. Rev.). See K. Webb, "Thumbs, Fingers, and Pushing on String: Legal Accountability in the Use of Federal Financial Incentives" (1993) 31 Alta. L. Rev. 501.

Report of the Auditor General of Canada 1986 (Ottawa: Supply and Services, 1986) c. 4.

The two categories are sometimes referred to as "normative" and "subsidizing" measures, respectively (see for example E. A. Zelinsky, "James Madison and Public Choice at Gucci Gulch: A Procedural Defense of Tax Expenditures and Tax Institutions" (1993) 102 Yale L.J. 1165. For a good overview of conceptual issues relating to tax expenditures, see N. Bruce, "Pathways to Tax Expenditures: A Survey of Conceptual Issues and Controversies" (Working Paper No. 90-1) (Ottawa: Tax Policy and Legislation Branch, Dept. of Finance, 1990) [hereinafter "Pathways"] reprinted in N. Bruce, ed., Tax Expenditures and Government Policy (Kingston: John Deutsch Institute, Queen's University, 1990). 
regard will be feasible until there is clearer understanding of the conceptual difficulties that have plagued accountability in taxation.

The analysis in the article is focused on income tax changes applying to the rental housing sector introduced by the federal government between 1972 and 1992. Limiting attention to a single sector over an extended period of time permits me to examine, in a tractable manner, the interrelationship between changes over time as policy makers respond to evolving policy concerns and objectives, thus providing focus and continuity. On the negative side, this approach precludes assessment of important thorny conceptual issues relating to the appropriate overall definition of the income tax base, and the unit of taxation. However, it is my view that a more wide-ranging study would likely only reinforce the conclusions reached in this article.

The study is structured as follows. Section II of the article presents a critical assessment of rental housing income tax changes introduced by the federal government over the past two decades. Section III provides a brief synthesis of the implications of the findings in section II for improved accountability in taxation and a sketch of the essential features of an integrated framework. Section IV of the article contains concluding comments.

\section{FEDERAL RENTAL HOUSING TAX CHANGES, 1972-1992}

In this section of the article, I assess income tax changes introduced by the federal government between 1972 and 1992 that specifically target the rental housing sector. I begin with a brief discussion of the criteria I apply in selecting relevant tax measures for inclusion. I then proceed to an assessment of the individual changes.

\section{A. THE CONCEPT OF NEUTRALITY}

The most relevant concept of which I am aware for identifying income tax changes applying to the rental housing sector is that of neutrality, the criterion used by the Department of Finance in compiling earlier tax expenditure accounts. ${ }^{5}$ Essentially, under the neutrality criterion, no differential tax treatment is given for any special circumstances applicable only to a particular group of taxpayers. As applied to the income tax, this criterion is basically analogous to the concept of horizontal equity that taxpayers in similar circumstances should pay the same amount of tax. ${ }^{6}$

I deviate in two main respects from the concept of neutrality as employed by the Department of Finance for identifying income tax expenditures. First, the Department

See "Account of the Cost of Selective Tax Measures" (Ottawa: Distribution Centre, Department of Finance, 1985) at 2 for a discussion of the concept of neutrality. The most recent tax expenditure account "Personal and Corporate Income Tax Expenditures" (Ottawa: Government of Canada, Department of Finance, 1993), does not explicitly mention the concept of neutrality; tax expenditures in that document are defined rather loosely against a representative benchmark tax system, but there does not appear to be any substantive difference in the measures included.

$6 \quad$ See for example R. Musgrave, Public Finance in Theory and Practice, 3d ed. (New York: McGraw-Hill, 1980) at 242 for a discussion of the horizontal equity principle. 
of Finance included only measures that were tax relieving in nature, while I include measures that are both positive and negative in effect. This is consistent with the focus of this article on accountability in taxation; whereas the tax expenditure accounts released to date have been more concerned with identifying selective tax measures that are roughly equivalent to direct expenditure programs. ${ }^{7}$ The problem with the expenditure-equivalence approach for present purposes is that it ignores selectively punitive measures; as we will see, it is particularly difficult to justify the exclusion of such measures in the context of the taxation of rental housing.

Second, my selection approach is more agnostic than that employed by the Department of Finance in that I attempt to include all measures that are selective in their impact, without at this point trying to establish whether or not they inherently "belong" - that is, whether they are primarily motivated by tax policy or tax expenditure considerations. I do this in an effort to avoid pre-judging measures in terms of their relation to any "ideal" benchmark tax system. Indeed, one important objective of this article is to assess the practicality of this concept and the implications for accountability of any obstacles to applying it consistently.

In summary, I attempt to identify any income tax changes over the twenty year period that target the rental housing sector, irrespective of whether the effect of the measure is positive or negative and without pre-judging the status of the measure in relation to some hypothetical benchmark tax regime. To err on the side of comprehensiveness, I include certain measures that target sectors closely related to the rental housing sector, such as the construction sector. To identify relevant measures, I undertook an historical search of revisions to the income tax legislation as well as of indirect sources such as federal government budget documents and master tax guides. ${ }^{8}$

\section{B. RENTAL HOUSING INCOME TAX CHANGES, 1972-19929}

The first tax change applying to the rental housing sector occurred in 1972, when a measure was introduced to the income tax regime that prevented individual taxpayers from deducting capital cost allowance (CCA) on a rental property that was in excess of the amount required to reduce rental income to zero from other sources of income. $^{10}$ As a result of this measure, CCA could be used to eliminate taxable rental income for the year, but it could not be used to create a loss that was deductible from other sources of income. Any excess CCA would have to be accumulated and carried forward to be deducted against future years' rental income.

The tax expenditure concept as originally developed was, in fact, articulated in terms of expenditure programs that were delivered through the tax system; see S. Surrey \& P. McDaniel, "The Tax Expenditure Concept: Current Developments and Emerging Issues" (1979) 20 Boston Coll. L. Rev. 225.

- Canadian Master Tax Guide (Montreal: CCH Canadian Limited, various years).

$9 \quad$ I would like to thank, without implicating, Anne Price and other officials at Central Mortgage and Housing Corporation for invaluable assistance in compiling the following list of rental housing tax measures. 
As background to understanding this measure, as well as a number of other changes that we will discuss, it is useful to review briefly the underlying concept of CCA. Rather than allowing the deduction of normal accounting depreciation from income, the tax system provides for the deduction of CCA, which differs in several fundamental ways from actual economic or physical depreciation. First, CCA rates provide, at best, only a very rough approximation of the true rates of depreciation that an accountant might use for book purposes. CCA is not particularly scientific in its application. It is permitted at more or less arbitrary rates on the combined values of groups (classes) of assets that are not necessarily of like kind, size or useful life; and no recognition is given to resale or scrap value until disposal of the asset actually occurs. Thus, the broad CCA classes and fixed CCA rates provide only an extremely rough approximation of the decline in an asset's value owing to both wear and tear and obsolescence.

Prior to 1972, rental buildings were included in two separate CCA classes. Wood frame buildings were included in Class 6, while Class 3 was the general category and included buildings not included in Class 6." The CCA rate for rental buildings in Class 3 was 5 percent and for Class 6 it was 10 percent, with both rates applied on a declining balance basis. It is difficult to determine whether or not the prevailing rates were, on average, appropriate. If, in fact, an asset's allowable CCA rate is in excess of the actual rate of depreciation for the asset, the CCA system allows an excessively large deduction from income when the asset is new, and a reduced deduction when the asset is older, than would otherwise be permitted. The net effect is that income tax is deferred. If only one rental property is owned, the tax deferral would cease when the property was disposed of because any excess of sales value over the undepreciated capital cost of the property would be required to be brought into income under the recapture provisions. ${ }^{12}$ In principle, tax deferral is equivalent to an interest-free loan from the government to the taxpayer. The value of such a tax benefit equals the interest rate times the amount of the effective loan - i.e. the amount of the tax deferred.

The second basic difference between CCA claimable and normal accounting depreciation arises from the general pooling of assets in CCA classes. Accounting depreciation is determined by reference to each asset individually. However, under the CCA system prevailing in 1972, rental properties were pooled in classes and the CCA

Income Tax Regulation, C.R.C. c. 945, s. 1100(1) and Schedule II [hereinafter ITR]. Class 3 also includes such dissimilar items as certain breakwaters, docks, trestles, windmills, and wharfs, while Class 6 also includes wooden breakwaters and wharfs, fences, oil or water storage tanks, greenhouses, aeroplane hangars, and certain railway equipment.

Income Tax Act, S.C. 1970-72, c. I-63, s. 13(1) [hereinafter ITA]. Prior to the 1972 taxation year, there was no capital gains tax. The part of the sales price received for a rental property that represented a recapture of CCA preciously claimed would certainly be taxable as ordinary income. Whether the remainder of the sales price would be treated as ordinary income or as a non-taxable capital gain depended on what Brown has referred to as "...the roulette wheel of the Tax Appeal Board and other court decisions relating to the ephemeral distinction between income and capital gains under Canadian tax law." See R. Brown, "A Critical Review of Tax Shelters: Loophole or Escape Hatch?" in W. Thirsk \& J. Whalley, eds., Tax Policy Options in the 1980s (Toronto: Canadian Tax Foundation, 1982) Canadian Tax Paper No. 66 at 127. Even after the introduction of capital gains taxation in 1972, the 50 percent inclusion rate on capital gains for tax purposes still left a major advantage to having gains classified in that category. 
rate was applied to the undepreciated capital cost (UCC) remaining in the class as a whole, rather than to the UCC for each asset separately. As a result of this, proceeds of disposition for a particular rental property simply served to reduce the total undepreciated value of the class as a whole. The proceeds of disposition from the asset were thus only brought into income at the declining balance CCA rate, rather than fully in the year of disposition. Net recapture amounts could, therefore, be deferred well beyond the time of disposition of the individual assets if other rental properties were acquired in the same class. Similarly, there was a corresponding deferral in the recognition of losses when the asset was sold for less than its depreciated value.

A third feature of CCA that differs from true depreciation is the discretionary nature of CCA claims. If a taxpayer does not have sufficient taxable income, he does not need to claim all, or indeed any, of the CCA available to him in that year; he can accumulate unclaimed CCA year-to-year and claim it in a future year. In this way, taxpayers avoid creating a tax loss that is subject to a time limit on when it can be written off against other income. ${ }^{13}$ Moreover, the ability of a taxpayer to exercise discretion about when he will claim CCA permits tax planning opportunities by permitting him to deduct CCA losses from non-rental sources of income in years in which he is in the highest tax brackets.

For rental properties in 1972, CCA and book depreciation also differed in their respective treatments of interest payments relating to the acquisition of the capital asset. For accounting purposes, interest payments incurred in getting an asset into use are capitalized in the cost of the asset and depreciated along with the capital cost of the asset slowly over time, rather than being immediately expensed. In 1972, for tax purposes, all interest payments were permitted to be expensed in the year they were made.

The final difference between CCA and depreciation relates to when deductions start for tax and accounting purposes. Accounting practices use the "put-in-use" rule, whereby no depreciation is recorded in the company's books until the asset is actually put in use. For example, no depreciation is claimed throughout the period in which an asset is being constructed. In 1972, however, CCA on a rental property could be claimed for tax purposes from the day of acquisition - that is, from the day that title to the property was acquired by an investor. Obviously, in the case of rental buildings under construction, there could be a significant timing differential between when depreciation was taken for tax purposes versus when it was taken for book purposes.

With this background on the operation of the CCA system as it applied to rental housing in 1972, it is now appropriate to reflect on the implications of the CCA loss restriction introduced in that year in terms of the tax policy/tax expenditure dichotomy referred to earlier. The need for the loss restriction presumably derived from a view that the CCA rates in the case of rental buildings were somehow excessive and thus constituted an explicit violation of general tax policy principles - namely, the calculation of true income. For this to be meaningful, the concept of accelerated CCA 
must be amenable to reasonably precise interpretation relative to true depreciation. However, the discussion above indicates that this is far from the case. Moreover, the tax expenditure status of accelerated CCA has been challenged by various authorities, for example Fiekowsky, ${ }^{14}$ who argues that it is impossible to calculate taxable income without allowance for $\mathrm{CCA}$, and that identification of the exact reference rate for measuring accelerated CCA is next to impossible. At least indirect support for the Fiekowsky view is provided by the fact that in 1983, the Special Analysis G of the U.S. Treasury began omitting the Accelerated Cost Recovery System (ACRS) from its list of tax expenditures. On the other hand, Surrey and McDaniel have strongly criticized the view that ACRS is normative on the grounds that arbitrary differences in CCA rates across different assets produces "highly varying effective rates of tax." 15 Thus, the tax expenditure status of accelerated CCA is itself somewhat controversial.

Ignoring for now the enigmatic nature of the accelerated CCA concept, it is possible that policy makers intended to set high CCA rates for rental housing units in order to achieve policy objectives, such as encouragement of investment in the sector or indirect subsidization of renters. ${ }^{16}$ If so, it seems paradoxical and counter-productive, at least at face value, to have introduced a loss restriction that partly negated the effectiveness of the accelerated CCA rate. Accelerated CCA would improve the expected after-tax return on rental investment, irrespective of whether the excess CCA was deducted from positive rental income or from income from other sources of the taxpayer. It is difficult, therefore, to rationalize on tax expenditure grounds allowing the deduction from positive rental income but not from other sources of income as well. This is especially true since such targeting of the incentive could potentially be quite perverse; the operating losses on rental properties would presumably be most likely to occur in the early years of an investment, precisely the point at which it might seem most reasonable to permit full CCA deductions from non-rental income. It is also odd that the CCA loss restriction applied to properties in both Class 3 and Class 6, despite the substantial rate differential between the two classes.

Apparently, however, there was a dominating equity concern, if for no other than reasons of perception, with the overt reduction of tax liability on non-rental income through rental investments. However, the loss restriction is not defensible on horizontal equity grounds since high income investors with equivalent incomes and whose rental operations differed only with respect to their ability to absorb CCA deductions, could wind up paying different amounts of tax. Indeed, in the presence of true accelerated $\mathrm{CCA}$, the concept of horizontal equity is largely irrelevant anyway, since the provision

14 S. Fiekowsky, "The Relation of the Tax Expenditure to the Distribution of the Fiscal Burden" (1980) 2:4 Can. Taxation 211.

is $\quad$ S. Surrey \& P. McDaniel, Tax Expenditures (Cambridge Mass.: Harvard University Press, 1985) at 210 .

16 If successful, it would do this by lowering the after-tax cost of rental housing investments. The apportionment of the resulting benefit between investors and renters would depend on the competitive characteristics of the rental housing sector - most importantly, the elasticity of supply of units with respect to after-tax return. For a discussion of effective tax rates on capital income, see R. Boadway et al., Taxes on Capital Income in Canada: Analysis and Policy (Toronto: Canadian Tax Foundation, 1987) Canadian Tax Paper No. 80, especially c. 2. 
inherently entails different tax burdens being imposed on different taxpayers with equivalent ability to pay. Thus, the desire on the part of policy makers to constrain tax shelter activity, based on some more vague, more pragmatic concept of equity, seems to have dominated both narrow considerations of horizontal equity and, possibly, effectiveness in tax expenditure delivery. As will be noted from subsequent discussion, there is in the rental area an ongoing tension between tax policy principles (including that of horizontal equity), more general equity concerns (or at least perceptions) and pursuit of tax expenditure objectives.

A second measure that targeted the rental housing sector was also introduced in 1972. In that year, a further restriction required that all rental properties with a capital cost in excess of $\$ 50,000$ be put in a separate CCA class. ${ }^{17}$ This constituted a deviation from the general principle of asset pooling under the CCA system. The change prevented the deferral of recapture when a rental property was sold, through the acquisition of other properties that were in the same CCA class.

The tax authorities may have felt that opportunities for deferring tax were more common in the case of rental properties than for other assets because of the greater likelihood that the former would increase in value over time or, more generally, because CCA rates were felt to exceed true depreciation rates for that category. The effect of this restriction was to limit the tax deferral advantage of accelerated CCA to the period for which the investor owned the original property. While this change is superficially consistent with generally accepted accounting principles, the precise policy objective of this is unclear in the presence of intentionally accelerated CCA. Limiting the duration of the tax deferral to the holding period for the original unit is arbitrary, lowers the tax advantage of investing in the original property, and should serve to slow down the turnover of originally subsidized properties. Thus, this measure brought in a further, somewhat arbitrary limitation to what appears to be a tax expenditure (accelerated CCA). This measure appears to have been motivated by a desire to refine the measurement of true income, although only partially and in an ad hoc manner. ${ }^{18}$

In 1974, a new measure prevented land developers from deducting property taxes and interest expenses relating to idle land from income from other sources. ${ }^{19}$ As discussed above, the treatment accorded carrying charges on rental property for accounting purposes is capitalization of such costs into the undepreciated capital value associated

SOR/72-274, s. 2.

18 It should be noted as well that both of the changes introduced in 1972 have implications for provincial government revenue collections. This is because CCA affects basic federal tax liability, which forms the basis for the calculation of liability for provincial tax in all provinces except Quebec, which has its own individual tax system. Similar affects arise in the case of various other measures - for example, investment tax credits or deductions for interest and "soft costs" (see below) - that alter, either directly or indirectly through their interaction with other provisions, basic federal tax. In such cases, the federal government does not bear all of the financial cost or reap all of the financial reward, as the case may be, for changes made. This raises a concern similar to that noted by Webb, supra note 2 , about the lack of a clear-cut boundary that distinguishes between federal and provincial jurisdiction. 
with such assets. In this case for tax purposes, however, we have denial of current expensing of such costs in the case of undeveloped land but, as yet, no general provision for the capitalization of such expenses into the adjusted capital cost base.

There are two possible interpretations of the factors that might have motivated this change. One interpretation is tax policy based. The tax policy concern may have been that, with capital gains now taxable (but with only a 50 percent inclusion rate and only on a realization, not an accrual basis), deduction of carrying charges on idle land from other sources of income provided particularly attractive tax shelter opportunities. This would occur if the land appreciated in value, was sold and qualified as a capital gain for tax purposes. Under this interpretation, then, the measure could be viewed as partial compensation for other deficiencies in the income tax legislation - namely, the treatment of capital gains and the failure of the tax system to fully compensate for the effects of inflation.

A second possible interpretation is tax expenditure based. Under this interpretation, the restriction could have been intended to stimulate a slow-down in rental housing unit starts by encouraging developers to get more land into active use. ${ }^{20}$ Thus, because of imperfections in the design of the tax system, it is quite possible for the same measure to be characterized in completely different terms - a not uncommon occurrence. The structural imperfections that arise in this case with respect to the taxation of capital gains and interest are evidence of a difficult conceptual issue that has never been resolved under any income tax regime. Because it has proven impractical to design an income tax system that is fully indexed for inflation and that taxes 100 percent of real capital gains on an accrual basis, arbitrary compromise provisions are inevitably introduced that themselves often give rise to myriad tax shelter opportunities. Patchwork anti-avoidance rules introduced to plug holes arising from the compromise provisions are often virtually impossible to distinguish from tax expenditure provisions. Even where, as in this case, the measure appears restricting in nature, it can have tax expenditure-like effects and motivations.

In the same year (1974), the Multiple Unit Residential Building (MURB) program was introduced to the income tax system. ${ }^{21}$ Under the MURB rules, investors in apartments, row housing and semi-detached housing units that were certified by Central Mortgage and Housing Corporation to be MURB properties were permitted an exemption from the general rule disallowing the deduction of CCA-generated losses on a rental property from income from other sources. To be certified as a MURB, not less than 80 percent of the floor space of the building had to be used to provide selfcontained domestic establishments and related parking, recreation, service and storage. For eligibility, construction had to begin between November 18, 1974 and the end of 1975 (extended later in 1974 to units begun prior to January 1, 1978).

21 ITR, supra note 11, Schedule II, Class 31 and Class 32 . Units qualifying as MURBs fall within Class 31 and Class 32, where they would otherwise fall, respectively, within Class 3 or Class 6. 
The MURB provision also has a murky underlying motivation. ${ }^{22}$ The provision added to the growing contortions of the tax rules relating to rental investments, which now consisted of the following: apparently accelerated CCA rates (presumably to stimulate investment); a restricting provision that targeted the CCA deduction to positive rental income; a special rule that required that investments relating to most units be classified in separate CCA classes; and now selective relief from the CCA loss rules for certain certified rental investments. It is futile to attempt to disentangle tax expenditure policies from the strict underlying tax policies. Specifically, it is impossible to decipher whether the MURB rules are the norm or the exception; that is, whether CCA loss deduction is deemed acceptable on tax policy principles for this limited category of rental investments, or whether the MURB rules are an attempt to stimulate investment or subsidize renters in a controlled manner, at the expense of otherwise appropriate tax rules.

In 1976, a change was made, to the income tax loss rules requiring that terminal losses relating to a given CCA class be deducted in the year of the asset's disposition. ${ }^{23}$ This prevented the carry-over of terminal losses to be applied against income in other years in which the taxpayer had high income from other sources and hence was in a high marginal tax bracket. In the same year, it was also made mandatory that any negative balance in the undepreciated capital cost of a class of depreciable property be recaptured in that year. ${ }^{24}$ This prevented the carryover of amounts for recapture to years in which the taxpayer might have a lower taxable income and thus be in a lower marginal tax bracket. Both of these changes are consistent with accounting practices relating to depreciation, although they are less obviously appropriate in the context of the CCA regime which permits total discretion with respect to the carry-over of accumulating CCA. Also, even if the changes are reasonable on tax policy grounds, their tax expenditure-like effects cannot be ignored; in addition to any improvement in the measurement of taxable income, the measures could also potentially affect the after-tax rate of return in rental markets - effects which should properly be weighed in any assessment of the measures.

In 1977, a measure was introduced that permitted expenses incurred in disposing of depreciable property to be deducted from the proceeds of disposition in determining recapture or eligible capital amounts. ${ }^{25}$ Recognition of disposal costs for tax purposes resulted in a more accurate measure of the true net gain for tax purposes. It, therefore, fostered attainment of tax policy objectives although, again, potential effects on rental markets cannot be ignored. While not particularly an issue in the present context, the question also arises as to when such "inherently correct" changes are worth doing in cases where issues of tax abuse and administrative compliance costs must be balanced against any improvement in the definition of the tax base. I raise this here only to point out that this is an issue that would often have to be confronted in evaluating particular

For a discussion of some of the underlying considerations behind the MURB provision, see Good, supra note 20.

$23 \quad I T A$, S.C. $1977-78$, c. 1, s. 14(4).

$24 \quad I T A$, S.C. $1976-77$, c. 4 , s. 13(1).

2s ITA, supra note 23 , s. $6(10)$. 
provisions, emphasizing again that many tax policy changes have an element of arbitrariness and imprecision, and inevitably entail resource costs and benefits.

In 1978, a reduction in the CCA rate on wood frame buildings from 10 percent to 5 percent effectively achieved symmetry across building types. ${ }^{26}$ As a result of the change, frame buildings on which construction commenced after 1978 or that were acquired after 1978 were to be included in Class 3 (the 5 percent CCA class) rather than Class 6 (the 10 percent class). ${ }^{27}$ Whether or not the change was desirable on strict tax policy grounds (i.e. in terms of the correct measurement of taxable income) depends crucially on the appropriateness of the 5 percent rate for all types of rental units. However, even if this is reasonable, it is difficult to justify the earlier restrictions (e.g. the CCA loss restriction, the separate class requirement, etc.) imposed on assets in Class 3; it would seem that they should only have been imposed on assets in Class 6 . Determination of whether the change was desirable on tax expenditure grounds depends on the much larger issue of the effect on total net social benefits from resource reallocation that result from the change. Even if the rate change was the "correct" thing to do on tax policy grounds, determination of whether it was, on balance, desirable still requires weighing of the resource reallocation effects in a manner that is equivalent to assessing a tax expenditure change. It is difficult to see why there should be any substantive difference from the perspective of accountability in taxation.

Before proceeding, it is worth noting that none of the other measures described above that restricted CCA claims were modified as a result of the CCA rate reduction for rental properties previously included in Class 6 . This is in spite of the fact that under perhaps the most reasonable interpretation, those restrictions were motivated by a perception on the part of tax authorities of excessive rental CCA rates. In my view, this highlights the significant element of arbitrariness in the changes.

Also in 1978, the MURB program was extended to $1979 .{ }^{28}$ In that year as well, interest and property taxes on land held by developers that were incurred after November 16, 1978 were permitted to be deducted from other income as they were incurred. This reversed the earlier restriction introduced in 1974. The same sorts of evaluation questions that originally arose because of the ambiguous objectives of both of these measures obviously arise again here with the reversal in the original restrictions.

In 1979, a new measure required certain "soft costs" to be deducted over the period to which they related. The term "soft costs" refers to such costs as interest expenses, promotional costs, legal fees, and so on made or incurred during the period of the construction, renovation or alteration of a building. Policy concerns in this area have centred around the fact that a tax shelter opportunity can arise if the expenses are permitted to be fully deducted when incurred, when, in fact, they may relate to a much

SOR/78-949, s. 3.

However, additions or alterations to most Class 6 buildings after 1978 continued to be included in Class 6 if the additional cost did not exceed $\$ 100,000$.

Supra note 26. 
longer period - up to and including the full life of the building. As a result of the new measure, for example, fees for a cash flow guarantee for a period of five years would have to be prorated over that five-year period rather than deducted when paid or incurred. This measure would seem to be strictly tax policy motivated - in this case to achieve a more accurate approximation of true profit - although the by now recurring proviso about the need to also weigh potential efficiency effects and any extra compliance and administrative burdens obviously applies.

In 1980, the MURB program (which had been allowed to expire in 1979), was reintroduced for buildings on which construction began between October 28, 1980 and January 1, 1982. To my knowledge, no rigorous assessment or justification of the appropriateness of this extension was undertaken.

The half-year rule, introduced in 1981, limited the amount of CCA deduction to onehalf of the regular rate in the year an asset was acquired. ${ }^{29}$ This provision was apparently intended to remove the favourable tax treatment previously accorded asset acquisitions that were made late in the year, but for which a full-year CCA claim could still be claimed. While this might seem reasonable on tax policy grounds, such a view must be tempered by reflection upon the considerable arbitrariness of the fixed-rate CCA regime. The provision would limit the tax advantage of strategic asset acquisitions near the end of a tax year, but whether it would, on average, result in a more or less accurate calculation of true income is a debatable point.

A 1981 measure restricted the exemption from capital gains tax for principal residences to one principal residence per married couple. ${ }^{30}$ The primary effect of this for rental markets was to lessen the attractiveness of owning and renting out secondary residences. It is impossible to justify the principal residence exemption on tax policy (e.g. horizontal or strict vertical equity) grounds. Aside from straight political motivations, residences may have been exempted to encourage home ownership - that is, on tax expenditure grounds. The subsidy would lower the potential long-run after-tax cost of home ownership versus renting and encourage the former at the expense of the latter. It would also result in a lower long-run tax burden on home owners than on renters, bearing in mind the overall burden of all taxes taken together. Restricting the exemption to principal residences obviously reduced the tax break for owners of multiple properties, while not altering the spirit of the original exemption; indeed, it would undoubtedly focus the exemption more in the direction that was originally intended. It could thus be viewed as more tightly focusing a tax expenditure, although it leaves unanswered the question of whether the tax expenditure is ultimately desirable.

A change in 1982 relating to lease-leaseback arrangements eliminated a previous exemption that permitted full CCA-generated loss deductibility in cases where a rental property was built on land leased from its owner and subsequently leased back to him or her. ${ }^{31}$ A change to the terminal loss rules was also introduced in 1982 relating to

P.C. 1983-1083, s. 1(2).

ITA, S.C. $1980-83$, c. III-140, s. 23(3).

SOR/82-599, s. 1(4). 
demolition or other disposition of buildings. If the taxpayer owned other buildings, the loss was required to be added to the capital cost of the other buildings and depreciated along with that cost. If the taxpayer did not own any other buildings but owned land, the demolition or disposal costs would be added to the cost base of that land, thus reducing the amount of any capital gain realized on the land. In all other cases, one-half of the terminal loss associated with the demolition would be treated as a business loss.

Prior to the new terminal loss rules, it was often advantageous for the vendor to tear down an existing building and sell the land in cases where the purchaser was interested only in the land. This would avoid the recapture of capital cost allowance in respect of the building, trigger a terminal loss on the building, and would permit the vendor to take his or her overall profit on the transaction as a capital gain on the land; at that time, only 50 percent of such capital gain was included in income for tax purposes. The taxable capital gain would be offset in whole or in part by the terminal loss. While probably intended as a strict tax policy improvement, it should be emphasized again that the potential gain in tax equity has to be assessed in the context of full efficiency and equity effects as well as potential extra compliance and administrative costs.

At that time as well, a new measure required the capitalization of soft costs into the cost base for the real property to which they related. ${ }^{32}$ As a result of this measure, soft costs would be deducted according to CCA rates applying to the undepreciated capital cost base for a building, rather than being deducted immediately when made or incurred. The provision did not apply to corporations whose principal business activity was renting or leasing real estate; these corporations would be permitted to continue deducting soft costs. The change was obviously an attempt to apply generally accepted accounting principles within the context of the CCA regime. The change also disallowed a deduction for carrying costs of land adjacent to uncompleted buildings. This prevented circumvention of the general disallowance of deduction of carrying costs that might otherwise be possible for certain idle land, owing merely to the land's proximity to a construction site.

Beginning in 1982, the half-year rule was also extended to MURB designated properties. This meant that new MURBs constructed in 1982 could claim only half of the regular CCA allowance in that year. The escalating arbitrariness of succeeding measures should not escape the attention of the reader.

Another measure was introduced in 1982 that once again illustrated the recurring trade-off between tax policy goals and potential effects on rental markets. For that year and subsequent years, interest and property tax expenses incurred to earn investment income from property could only be deducted to the extent of such income (exclusive of capital gains) for the year, with any excess carried forward against future investment income. This restriction, which applied to both MURB and non-MURB rental properties, prevented the deduction of interest-generated losses from other income sources of investors. This reduced the tax advantage arising from immediate deduction of full nominal interest charges (including the inflation expectations component) when 
appreciation in the rental property value often received preferential and deferred capital gains treatment. The measure did not apply on funds borrowed to finance rental property acquired before November 12,1981. Comments made earlier about the difficulty of classifying the status of specific measures in the presence of inevitable overall structural imperfections in the tax legislation apply for this measure as well.

In the same year, a reserve was permitted for the profit attributable to unpaid instalments associated with the disposition of real property that give rise to ordinary income. This, of course, did not affect rental investors who were accorded capital gains treatment on the sale of their property.

The "put-in-use" rule introduced in 1987 placed restrictions on the timing of the commencement of CCA deductions in respect of an asset acquired after 1989. Commencing in that year, CCA deductions could only begin at the earlier of the year the property was first available for use, and two years after the date of acquisition by the taxpayer (in which case the half-year rule would not apply). In the context of rental housing property, this restriction prevented CCA deductions in respect of property that was not immediately placed in active use by the owner and was undoubtedly intended to pattern generally accepted accounting principles.

Beginning after 1987, an additional measure further reduced the attractiveness of CCA deductions on buildings by lowering the CCA rate from 5 percent to 4 percent. With this change, buildings acquired after 1987 were now included in Class 1, Schedule II to the Income Tax Act - the 4 percent class. As in the case of the earlier changes to the allowable CCA rate on rental buildings, no change was made to any of the unique restrictions applying to such investments.

Also in 1987, a measure was introduced that phased out the 1981 exemption for principal business corporations from the soft cost capitalization rules, thus placing them on the same footing as unincorporated taxpayers. ${ }^{33}$ The phase-out was according to the following formula: $1988-20$ percent of soft costs must be capitalized; $1989-40$ percent; 1990 - 60 percent; $1991-80$ percent; 1992 and subsequent years - 100 percent.

1987 also saw the introduction of a measure that required carrying charges on vacant land owned by land developers or sellers, and on vacant land held in the course of business to be capitalized subject to the same transitional period as for soft costs. This prevented the tax advantage of full nominal interest deduction when there might be preferential and deferred capital gains treatment for the appreciation of associated land.

In the same year, the tax shelter for investments in existing MURBs ended. Persons who acquired existing MURBs after June 17, 1987 were no longer allowed to create tax losses by deducting depreciation against other income, and after 1990 (subsequently extended to after the end of 1993), existing MURB owners would not be able to create such losses. 
The cumulative net investment loss (CNIL) rules, which in many cases reduced the attractiveness of owning rental properties, were introduced in $1988 .{ }^{34}$ Under the CNIL rules, certain investment expenses for a capital property, including interest and carrying costs, were to be accumulated and applied to reduce the individual's capital gains exemption - at that time equal to $\$ 100,000$. The capital gains exemption was obviously a contentious measure on either tax policy or tax expenditure grounds - the former because it is difficult to see how it could possibly, on average, improve the measurement of true income; the latter because it did not grandfather gains accumulated to the coming-into-force date and because it applied indiscriminately to all types of capital assets. While the CNIL rules limited the magnitude of the exemption in some cases, it did so in an arbitrary fashion, apparently based loosely on a desire to avoid compounding of structural imperfections in the tax system. The rules thus have complex equity implications which should properly be considered in conjunction with any resource reallocation effects resulting from the changes.

In 1992, secondary residences were made ineligible for the $\$ 100,000$ capital gains exemption. This further reduced the attractiveness of holding secondary properties for rental purposes and would hence potentially affect the supply and price of rental properties. The change reflects, as well, the previously noted reality that strict tax policy principles often seem to be inappropriately violated in the pursuit of social policy objectives. Without meaning to defend the capital gains exemption, it is difficult to see how, on grounds of horizontal equity in taxation, one could justify the unique exclusion of secondary residences when other equally questionable assets continue to be eligible.

\section{IMPLICATIONS FOR ACCOUNTABILITY IN TAXATION}

In my view, the overriding conclusion that emerges from this review of rental housing tax changes is that attempts to distinguish tax policy from tax expenditure changes should be abandoned for the following reasons: the appropriate tax principles that should guide specific tax changes are vague in many instances so that it becomes difficult to distinguish between measures that are motivated by tax policy rather than tax expenditure considerations; even where underlying tax principles are reasonably clear, considerable ambiguity arises with respect to the status of particular measures, either because of the inability of legislation to capture those principles precisely or because of apparent unwillingness of tax policy makers to approximate those principles more closely, particularly in instances where concepts of social equity conflict with the narrower concept of horizontal equity in taxation; as a result of the interrelationships among different tax provisions, meaningful classification of measures over time becomes difficult as other parameters of the tax system change; and, perhaps most important of all, even relatively clear-cut tax policy changes often have effects that are indistinguishable from tax expenditure changes and vice versa, making the tax policy/tax expenditure distinction largely irrelevant. As a result of these considerations, it is my opinion that an integrated approach to tax policy design and evaluation is 
necessary - one which takes into account the totality of the effects of particular changes.

The theoretical underpinnings for such an approach are readily available from standard concepts in analytical welfare economics. ${ }^{35}$ However, those principles have not been consistently applied in the design and evaluation of tax changes, in large part I think because of the pervasiveness of the tax policy/tax expenditure dichotomy in the minds of policy makers. The principle characteristic of this approach is assessment of the full equity and efficiency effects ${ }^{36}$ of all measures, with no attempt to distinguish between those measures that intrinsically form part of the tax system and those measures intended to accomplish specific social or economic objectives. In my view, it is precisely the attempt to maintain this largely artificial distinction that has stifled progress in tax evaluation and accountability.

Tax measures, as with any policy initiatives, essentially have only two potential economic effects - they may cause the total real value or composition of resources available to society to change or they may cause the distribution of resources among members of society to change. Measures that cause the total real value of resources or the composition of real resources to change are generally described as having efficiency effects; those that cause the distribution of resources to change are generally referred to as having equity effects. The essential point that I think is established by the preceding review of rental housing tax changes is that most tax changes typically result in both effects. Moreover, for effective assessment of tax measures to be possible, consideration of equity effects has to extend beyond narrow concepts of equity in taxation. These points can be best illustrated with a couple of specific examples.

Tax policies can induce efficiency effects in rental markets in myriad ways. For example, higher capital cost allowances or extension of the deferral period before any recapture is required would cause the cost of real capital investment to fall. This would have two principal efficiency effects: it would lower average costs, thus potentially stimulating investment in rental units; and would also induce an increase in the utilization of capital inputs relative to other factor inputs such as labour. The relative magnitudes of these effects are measurable through the application of appropriate modelling techniques. In addition to the efficiency effects, however, the measures would cause tax burdens on rental investors to fall - thus entailing horizontal equity and elements of vertical equity tax effects - and, also, create a potential benefit to renters through reduced rents. All of these effects have to be assessed jointly in the context of particular economic conditions, including conditions in rental markets and prevailing social and economic objectives. Similarly, a measure such as a requirement that land carrying costs be capitalized will not only entail horizontal equity effects and

Excellent expositions of standard principles of welfare economics can be found in $\mathrm{R}$. Boadway \& N. Bruce, Welfare Economics (Oxford: Basil Blackwell, 1984) c. 5, and D.M. Winch, Analytical Welfare Economics (Harmondsworth: Penguin Books, 1971).

36 B.I. Bittker, "Equity, Efficiency, and Income Tax Theory: Do Misallocations Drive Out Inequities?" in H. Aaron \& M. Boskin, eds., The Economics of Taxation (Washington: Brookings Institution, 1980) has also noted the need for a unified framework for assessing the equity and efficiency of tax policies. 
thus have implications for the attainment of tax objectives, it will also cause resource reallocation (efficiency) effects and larger resource distribution (equity) effects that extend beyond the distribution of tax burdens.

Before concluding this section, a few comments should be made about how administrative and compliance costs would be handled within the integrated framework. Concern is often expressed about these whenever the tax system is used to accomplish specific social or economic objectives. ${ }^{37}$ As mentioned in the preceding section, however, these costs arise with any change in the tax regime, irrespective of the underlying motivation of the change. ${ }^{38}$ These costs are best viewed as a specific component of efficiency effects of tax changes. Any assessment of a tax change should evaluate carefully the extra burden that the measure imposes on revenue officials. This can include the value of their time and any extra resources required to distribute policy information to select groups of taxpayers, to process additional tax return information, to certify investments or other criteria for eligibility, or to undertake required audit and tax compliance procedures. Evaluations should also consider the resource requirements imposed on the taxpayer in qualifying for the measure, including the value of his or her time and that of any tax professionals required. Similarly, when a restrictive tax measure has been applied to a particular activity to prevent tax abuse, any evaluation of the possible removal of the measure should not overlook potential increased compliance costs. Thus, administration and compliance costs can readily be accommodated within the framework I am suggesting.

\section{CONCLUDING COMMENTS}

In this article, I have reviewed federal rental housing income tax changes introduced over the period 1972 to 1992 with the intent of assessing their implications for tax policy evaluation and accountability. I conclude, on the basis of that review, that it is typically neither feasible nor meaningful to attempt to maintain a distinction between, on the one hand, measures that are introduced to achieve strict tax policy objectives and, on the other hand, measures that are introduced to achieve tax expenditure objectives. An integrated approach to tax policy design and evaluation is required. Such an integrated approach would ideally ensure that all potential ramifications of all types of tax changes are thoroughly taken into account. This would lay the groundwork for improved accountability in tax policy, and address the sorts of legal concerns raised by $\mathrm{Webb}^{39}$ and noted earlier. Although the article did not address issues relating to legal structures and channels of accountability, it is unlikely that substantive improvements in these areas will be feasible until there is resolution of the conceptual difficulties (discussed in this article) that have plagued accountability in taxation. While a thorough

See for example the comments by Brooks in "Pathways", supra note 4 at 324, who argues that administrative and compliance costs are particularly significant for tax subsidies and incentives because of the utilization by many taxpayers of highly knowledgeable legal and accounting expertise to circumvent the rules.

For an analysis of these costs in the case of the Canadian income and payroll tax systems, see $F$. Vaillancourt, The Administrative and Compliance Costs of the Personal Income Tax and Payroll System in Canada, 1986 (Toronto: Canadian Tax Foundation, 1989) Canadian Tax Paper No. 86. 
development of the integrated approach is beyond the scope of this article, I have attempted to outline the essential features that would comprise such an approach from an economic perspective. 